\title{
The configural approach to organisational commitment: An application in Ghana
}

\begin{tabular}{|c|c|}
\hline \multicolumn{2}{|c|}{$\begin{array}{l}\text { Authors: } \\
\text { Edward O. Akoto } \\
\text { Eunice V. Akoto }\end{array}$} \\
\hline \multicolumn{2}{|c|}{$\begin{array}{l}\text { Affiliations: } \\
1 \text { School of Business, } \\
\text { Henderson State University, } \\
\text { United States of America }\end{array}$} \\
\hline \multicolumn{2}{|c|}{$\begin{array}{l}\text { 2Department of Public } \\
\text { Administration, North } \\
\text { Carolina Central University, } \\
\text { United States of America }\end{array}$} \\
\hline \multicolumn{2}{|c|}{$\begin{array}{l}\text { Correspondence to: } \\
\text { Edward Akoto }\end{array}$} \\
\hline \multicolumn{2}{|c|}{$\begin{array}{l}\text { Email: } \\
\text { akotoe@hsu.edu }\end{array}$} \\
\hline \multicolumn{2}{|c|}{$\begin{array}{l}\text { Postal address: } \\
\text { PO Box 7660, Arkadelphia, } \\
\text { AR 71999, United States } \\
\text { of America }\end{array}$} \\
\hline \multicolumn{2}{|c|}{$\begin{array}{l}\text { Dates: } \\
\text { Received: } 13 \text { Mar. } 2014 \\
\text { Accepted: } 07 \text { Oct. } 2014 \\
\text { Published: } 10 \text { Dec. } 2014\end{array}$} \\
\hline \multicolumn{2}{|c|}{$\begin{array}{l}\text { How to cite this article: } \\
\text { Akoto, E.O, \& Akoto, E.V. } \\
\text { (2014). The configural } \\
\text { approach to organisational } \\
\text { commitment: An } \\
\text { application in Ghana, } \\
\text { SA Journal of Industrial } \\
\text { Psychology/SA Tydskrif vir } \\
\text { Bedryfsielkunde, 40(2), } \\
\text { Art. \#1207, } 11 \text { pages. http:// } \\
\text { dx.doi.org/10.4102/sajip. } \\
\text { v40i2.1207 }\end{array}$} \\
\hline \multicolumn{2}{|c|}{$\begin{array}{l}\text { Copyright: } \\
\text { (C) 2014. The Authors. } \\
\text { Licensee: AOSIS } \\
\text { OpenJournals. This work is } \\
\text { licensed under the Creative } \\
\text { Commons Attribution } \\
\text { License. }\end{array}$} \\
\hline \multicolumn{2}{|l|}{ Read online: } \\
\hline 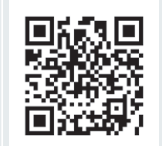 & $\begin{array}{l}\text { Scan this QR } \\
\text { code with your } \\
\text { smart phone or } \\
\text { mobile device } \\
\text { to read online. }\end{array}$ \\
\hline
\end{tabular}

Orientation: An emerging stream of research employs a configural or profile approach to the study of organisational commitment, by focusing on and placing individuals at the centre of data analysis. This approach signals the importance of taking a holistic view of individuals' commitment mind-set, unlike the variable-centred approach.

Research purpose: To test the theory on profiles of commitment in an African context (Ghana).

Motivation for the study: Although the three-component model of organisational commitment has been extended to several regions of Africa, there is a paucity of research on profiles of commitment on the continent.

Research approach, design and method: Cross-sectional data from two studies, with samples of 187 and 218, were analysed using k-means clusters. Multivariate analysis of variance (MANOVA) was then used to test the differences amongst profiles in their association with contextual variables, such as pay satisfaction, job security, strike propensity and two demographic factors.

Main findings: In the k-means cluster analysis, a six-cluster solution emerged in both studies; the profiles include the highly committed and the uncommitted groups, as well as the profiles based on normative commitment and continuance commitment. Overall, the MANOVA post hoc outcome shows that the highly committed group reports higher mean scores on the positive outcome variables (e.g. job security) than the uncommitted group. Conversely, the uncommitted group scored relatively higher on the negative organisational outcome (propensity to strike). Other mean differences were found in the respective studies on pay satisfaction, collectivism and the demographic factors.

Practical/managerial implications: Employing the configural approach to the study of commitment in this region should increase our understanding of the patterns of attachment and their influence on behaviour. Different patterns of attachment exist within the organisation that may be beneficial or detrimental to behaviour on the job. It is, therefore, important for managers to identify these patterns and target organisational policy and resources appropriately.

Contribution/value-add: This study applies the concept of commitment profiles to an untested region: an African context. It, therefore, adds to the literature on the generalisability of the typology of commitment profiles.

\section{Introduction}

Organisational commitment, an attachment to one's employing organisation, continues to interest researchers and managers and remains a vibrant research topic because of its central role in understanding and predicting workplace behaviour. Commitment research has mostly focused on the variable-centred approach (see Meyer et al., 2002), which identifies the differences in relationships between variables involving the three-component model of organisational commitment (discussed later). However, recent efforts have focused on a person-centred approach, termed the configuration or profiles of commitment (Meyer \& Herscovitch, 2001). The configural approach involves identifying homogenous subgroups of individuals within a population, groups that share similarities on the components of commitment (Kam, Morin, Meyer \& Topolnytsky, 2013; Sinclair, Tucker, Cullen \& Wright, 2005). Thus, commitment components may combine and relate differently to other variables within these subgroups. Hence, the defining feature of the configural approach is internal cohesion amongst profile members: the reliable occurrence of others. This concept assumes that research populations are not homogeneous and that the same theoretical framework and empirical findings may not apply uniformly to all sampled respondents (Meyer, Stanley \& Vandenberg, 2013). 
Whilst the three-component model has been applied in the African context (e.g. Beukes \& Botha, 2013; Simons \& Buitendach, 2013), little is known about the psychology of commitment profiles (configurations) and their effect on work outcomes. Thus, commitment profiles are an excellent means for gaining a better understanding of the dynamics amongst the three bases of commitment in relation to work outcomes (Somers, 2009), but there is limited research on the holistic view of commitment mindset using the threecomponent model of organisational commitment in an African context. The purpose of this study, therefore, is to test the concept of commitment profiles amongst samples of respondents from Ghana and to examine the credibility of the emergent clusters in terms of their relationships with a number of contextual variables and demographic factors. Consequently, the theoretical justification of this study lies in testing the generalisability of the configural perspective of commitment to an African country: Ghana.

Commitment is a psychological state and individuals may experience different bases of commitment simultaneously (Klein, Molloy \& Cooper, 2009). This mental frame may lead to a unique psychological state for employees in terms of their attachment to the organisation, with implications for job behaviours. Hence, the focus on the configural approach (person-centred), instead of the variable-centred approach, signals the importance of individuals in the work context (Meyer \& Herscovitch, 2001). According to Kam et al. (2013), the configural approach treats individuals in a more holistic fashion and allows commitment mindsets to be experienced differently and have different implications in combination than they do individually. Therefore, focusing on the psychology of commitment through configuration will provide new insight into the study of commitment and augment the variable-centred approach. The above suggests the possibility of a synergistic effect of the commitment components for organisations. The terms configural approach and profiles of commitment are used interchangeably in the rest of this article.

\section{Theoretical framework and background}

\section{The three-component model of organisational commitment}

Organisational commitment has been defined as the perceived bond or psychological attachment to the organisation (Klein, Brinsfield \& Molloy, 2006; cf. Klein, Molloy \& Cooper, 2009). Commitment to the organisation may take three forms, referred to as the three-component model (Allen \& Meyer, 1990). These include affective commitment (AC), attachment based on emotions or desire, continuance commitment (CC), attachment based on perceived cost, and normative commitment (NC), attachment based on perceived obligation (Meyer \& Allen, 1991). The three-component model of organisational commitment has been tested extensively in different settings (e.g. Meyer, Stanley, Herscovitch \& Topolnytsky, 2002), including non-Western contexts (e.g. Simons \& Buitendach, 2013; Wasti, 2002, 2005).

\section{The configural approach to organisational commitment}

Most research on commitment has been variable-centred, characterised by an emphasis on estimating the level of relationship between each form of commitment and their antecedents and consequences (Sinclair et al., 2005; Wasti, 2005; cf. Somers, 2009). The configural or profile approach to commitment research only gained a foothold in the literature recently, following the postulation by Meyer and Herscovitch (2001). The theoretical framework for codifying profiles of commitment by Meyer and Herscovitch has, therefore, energised research on commitment profiles. Eight commitment profiles were derived based on the relative levels of $\mathrm{AC}, \mathrm{CC}$ and $\mathrm{NC}$ ranging from highly committed (high AC, CC and NC) to uncommitted (low AC, CC and NC) (Meyer \& Herscovitch, 2001). Between these two extremes, there are six other commitment profiles. These include three commitment profiles that are characterised by high levels of two forms of commitment (i.e. affectivecontinuance dominant, affective-normative dominant and normative-continuance dominant). The other three profiles reflect attachment driven primarily by one form of commitment (i.e. affective dominant, continuance dominant and normative dominant) (Meyer \& Herscovitch, 2001; cf. Somers, 2009). See Table 1 for all profiles and descriptions. Table 2 contains samples of empirical research testing the configural approach and the postulations across countries. The reported profiles range from four-cluster to eight-cluster solutions. Although the research findings reported in the table may not be exhaustive, together they suggest that the eight-cluster solution may not always be replicated in all contexts or under all conditions.

In relation to outcome variables, Meyer and Herscovitch (2001) propose that the affective dominant profile would have a stronger (positive) influence on work outcomes than the continuance dominant and normative dominant profiles. Further, they suggest that the continuance and normative commitment components (either individually or conjointly) attenuate the positive influence of affective commitment on certain outcome variables.

TABLE 1: Meyer and Herscovitch's hypothetical profiles of organisational commitment

\begin{tabular}{|c|c|c|c|c|c|c|c|c|}
\hline \multirow[t]{2}{*}{ Commitment components } & \multicolumn{8}{|c|}{ Profiles } \\
\hline & High & AC-CC & AC-NC & $\mathrm{NC}-\mathrm{CC}$ & AC & $\mathrm{CC}$ & NC & Low \\
\hline$A C$ & Strong & Strong & Strong & Weak & Strong & Weak & Weak & Weak \\
\hline $\mathrm{CC}$ & Strong & Strong & Weak & Strong & Weak & Strong & Weak & Weak \\
\hline NC & Strong & Weak & Strong & Strong & Weak & Weak & Strong & Weak \\
\hline
\end{tabular}

$\mathrm{AC}$, affective commitment; $\mathrm{CC}$, continuance commitment; $\mathrm{NC}$, normative commitment. 
TABLE 2: Empirical test of the organisational commitment profiles across countries.

\begin{tabular}{|c|c|c|c|c|c|c|c|c|}
\hline \multirow[t]{2}{*}{ Countries } & \multicolumn{8}{|c|}{ Clusters } \\
\hline & High & AC-CC & AC-NC & NC-CC & AC & CC & NC & Low \\
\hline Tsoumbris and Xenikou (2010); four-cluster solution, $n=317$ (Greece) & Yes & - & Yes & - & - & Yes & - & Yes \\
\hline Somers (2009); five-cluster solution; $n=288$ (USA) & Yes & - & Yes & Yes & - & Yes & - & Yes \\
\hline \multirow[t]{2}{*}{ Wasti (2005); six-cluster solution; $n=941^{1}$ and $336^{2}$ (Turkey) } & Yes $^{1}$ & - & Yes & Neutral & Yes & Yes & - & Yes \\
\hline & Yes $^{2}$ & - & Yes & Yes & Yes & Yes & - & Yes \\
\hline Gellatly et al. (2006); eight-cluster solution; $n=545$ (Canada) & Yes & Yes & Yes & Yes & Yes & Yes & Yes & Yes \\
\hline
\end{tabular}

$\mathrm{AC}$, affective commitment; $\mathrm{CC}$, continuance commitment; $\mathrm{NC}$, normative commitment.

\section{Current study}

In the African context, research that has employed the three-component model of organisational commitment also focused on the variable-centred approach, with little or no test of the theoretical postulation of commitment profiles (based on our search of the literature). Whilst AC has been shown to be generalisable across most settings (Meyer et al., 2002), NC has been shown to be salient in a collectivist context (e.g. Wasti, 2002, 2005). Ghana, like other African countries, is classified as collectivist (e.g. Hofstede, 2001; House, Hanges, Javidan, Dorfman \& Gupta, 2004). Since prior research has shown that NC is salient in collectivist settings (e.g. Wasti, 2002), we expect that the salience of NC will be replicated in the Ghanaian context. In addition, Ghana is classified as a developing economy with high economic need (lower middle-income status) and high unemployment levels (The World Bank, 2012). Therefore, economic factors may be important to employees in their exchange relationships with organisations. Thus, CC may also be relevant in the Ghanaian context and may impact the profiles that emerge in this study. Since this study is exploratory in nature, we do not hypothesise the preceding arguments and assertions, but the study is guided by the following research questions based on these paradigms:

1. Are the configurations of commitment postulated based on western ideology generalisable to an African country like Ghana?

2. Are NC and CC dominant or conjoined profiles salient in this context?

3. How would the emerged profiles associate with outcome variables?

In response to these questions, secondary data from two different studies conducted at different periods in Ghana were analysed using k-means clustering to test the profiles of commitment. The emergent profiles were then correlated with contextual and demographic variables in both studies. These include pay satisfaction, job security, strike propensity, collectivism, age and tenure. The association with these variables and the demographic factors will provide a test of the discriminant validity of the profiles. The goal is to test the theoretical and empirical soundness of the profile groups that will emerge. We briefly expound on these variables before proceeding to describe the method and outcome of each study.

Both pay satisfaction and job security are important constructs to a study in a country in which unemployment is high, with perennial agitations for wage increases (Ghana News Agency, 2006). Pay satisfaction is the level of positive or negative feeling about pay and benefits (Heneman \& Schwab 1985; Williams, McDaniel \& Nguyen, 2006). Pay satisfaction is positively related to affective commitment and continuance (sacrifice) commitment, as well as normative commitment (e.g. Vandenberghe \& Tremblay, 2008). Job security is the perception of certainty in continuing one's present job (the opposite of job insecurity). Gaertner and Nollen (1989) reported that job security was positively related to organisational commitment. Their definition of commitment as non-instrumental attraction to and identification with the goals and values of the organisation makes it synonymous with AC. Thus, people who feel more secure in their job may experience higher emotional attachment to the organisation (AC dominant profiles). Conversely, job insecurity - the threat to continuity - was found to correlate negatively with AC and NC, but not CC (Bosman, Buitendach \& Laba, 2005). Hence, job security may associate positively with the commitment components.

Propensity to strike is a behavioural intention of work stoppage by employees who may or may not be union members (Cohen, 1992). It is the willingness to take part in activities that have negative implications for the employment relations. It is, therefore, a defiance of the organisation and, hence, a negative outcome (Cohen, 1992). Contrary to those who are committed, the uncommitted and dissatisfied members of the organisation may be more inclined to engage in this negative attitude. This construct was included in our analysis in view of the increased agitations for better working conditions by medical doctors and nurses (e.g. Ghana News Agency [GNA], 2011). Psychological collectivism is collectivism measured at the individual level of analysis. Collectivism is characterised by interdependence, norms that favour in-group embeddedness, duty and in-group harmony (Clugston, Howell \& Dorfman, 2000). The authors reported that collectivism correlates more positively with $\mathrm{NC}$ than $\mathrm{AC}$ and CC. We also included this construct in our analysis to test whether collectivist orientations will influence the kinds of profiles that emerges, particularly NC-based profiles.

Data from two independent studies were used, and it is important to emphasise that the data in study 1 overlaps with the data from the study by Akoto and Stammerjohan (in press), which was originally analysed with 141 data points based on the variable-centred approach. The sample in this study (study 1) is slightly bigger (187) and includes additional responses that were not used in the original study. One of the organisations sampled at the time did not approve the data collection until late in the process. Also, the primary 
focus of the original study was the influence of economic volatility on dual commitment (organisation and union). In the current study, we test the typology of commitment profiles (person-centred approach) using the threecomponent model of organisational commitment, with the additional data points. Similarly, the data for study 2 was not planned for profile analysis but was used to test the effect of perceived inflation on commitment and citizenship. Consequently, the analysis presented in this paper shares data with two primary studies. However, this study focuses on demographic and contextual variables that may not have been used in the original studies, or only used as control variables. Accordingly, the primary analysis and discussion presented in this paper are very distinct with different implications for research and theory.

\section{Study 1 \\ Method}

\section{Participants and procedure}

The sample consisted of medical doctors and nurses at three hospitals located in the southern region of Ghana. This sample was targeted due to the agitations for wage increases and involvement in strike activities by health care professionals (GNA, 2006, 2011). The survey questions were administered during work hours to respondents in the various departments of the hospitals (paper and pencil method). Out of the 600 distributed questionnaires, 187 were returned, representing an effective response rate of $31 \%$. The sample comprises 58\% female respondents (mostly nurses), which is representative of the health sector in Ghana (Ministry of Health, 2007). The average age and tenure were $38.19(\mathrm{SD}=12.16)$ and $8.98(\mathrm{SD}=5.88)$ years respectively. With respect to education, a little over $60 \%$ of the respondents reported having less than a university degree (Bachelor's), which is in line with the fact that majority of the sample are women who are predominantly nurses, since the minimum education required for their profession is a nursing diploma.

\section{Measures}

Organisational commitment was measured on the 18-item three-component scale developed by Meyer and Allen (1991), with six items each for AC $(\alpha=0.79)$, CC $(\alpha=0.70)$, and NC $(\alpha=0.82)$. For pay satisfaction, two items were adapted from the economic volatility and satisfaction measure by Akoto and Stammerjohan (in press) as a proxy for pay level satisfaction. The items are: 'I am severely underpaid' and 'I do not receive the required bonus for my work' $(\alpha=0.67)$. The items were reverse coded so that a higher score indicated high pay satisfaction. These two items were selected because they appear similar (face validity) to some of the items by Spector (1997), for instance 'I feel I am being paid a fair amount for the work I do' and 'I feel unappreciated by the employer when I think about what they pay me'. Job security was measured with a single overall question: 'I feel my job is very secure'. A higher score indicates high job security and vice versa. All the above scales were measured on a seven-point Likert response set.
Propensity to strike was measured with three items $(\alpha=0.90)$ as used by Cohen (1992, 2005). Respondents were asked: 'How many days would you participate in a strike: (1) regardless of the issue; (2) for a small (10\%) wage increase; (3) for a large (over $10 \%)$ wage increase'. The response set for all the items was: zero days (1), one week (2), two weeks (3), one month (4), two months (5) and more than two months (6). A higher score indicates a high willingness to engage in militancy.

\section{Data analysis}

Commitment profiles were generated using k-means clustering with standardised scores (z-scores) in SPSS 17.0 analytical program. The k-means clustering is an algorithm that groups cases in order to maximise the similarity within clusters and minimise dissimilarity amongst clusters based on their commitment scores (cf. Wasti, 2005). The number of clusters specified was guided by prior research (see Table 2 ), theoretical interpretability and cell sizes (observations per cluster) that are large enough for mean comparisons (Wasti, 2005). Multivariate analysis of variance (MANOVA) (in SPSS) was used to test for mean differences amongst the commitment groups on the outcome variables. MANOVA is a statistical method for comparing means of several groups, where there are two or more dependent variables (Hair, Anderson, Tatham \& Black, 2006). With respect to this study, it helps to determine whether different profile groups are differentially associated with the outcome factors. A significant multivariate F statistic indicates that the study variables differed across the groups. Univariate test with Scheffe post hoc multiple comparisons were then used to identify statistically significant differences amongst the profiles. The Scheffe post hoc test is the most conservative test in reducing Type I error (Hair et al., 2006).

\section{Results}

\section{Preliminary analysis}

Confirmatory factor analysis (CFA) was performed on the three-component model of commitment. The adequacy of the measurement model was estimated using the following fit statistics: chi-square-degrees of freedom ratio $\left(\chi^{2} / d f\right)$ of less than 3.0, comparative fit index (CFI), Tucker-Lewis index (TLI) and goodness of fit index (GFI) all greater than 0.95 and root mean square error of approximation (RMSEA) less than 0.08 , based on a sample size of less than 250 (Hair et al., 2006). The model proved adequate fit to the data with significant item loadings ranging from 0.50 to 0.90 , after eliminating problematic items (due to low inter-item correlation or cross-loadings). Thus, the fit of the measurement model was achieved when using four items for AC and three items each for both CC and NC, with the following fit statistics: $\chi^{2} /$ $d f=1.62, \mathrm{RMSEA}=0.067, \mathrm{TLI}=0.97, \mathrm{CFI}=0.98, \mathrm{GFI}=0.93$. The fitted number of items in this study are equivalent to the condensed scales (three items each) used in some studies (e.g. Gellatly, Meyer \& Luchak, 2006). The chi-square statistic was significant, but this is not uncommon in CFA tests (e.g. Wasti, 2005). The three-factor solution was a better fit than the other competing models examined: two-factor $\left(\chi^{2} / d f=2.21\right.$, 
TABLE 3: Means, standard deviations, and correlations amongst the study variables (study 1).

\begin{tabular}{|c|c|c|c|c|c|c|c|c|c|c|}
\hline Variable & Mean & SD & 1 & 2 & 3 & 4 & 5 & 6 & 7 & 8 \\
\hline 1. $\mathrm{Age}^{\mathrm{a}}$ & 38.19 & 12.16 & - & - & - & - & - & - & - & - \\
\hline 2. Tenure ${ }^{b}$ & 8.98 & 5.88 & $0.78 * *$ & - & - & - & - & - & - & - \\
\hline 3. $\mathrm{AC}$ & 4.92 & 1.35 & $0.17^{*}$ & 0.09 & 0.79 & - & - & - & - & - \\
\hline 4. CC & 3.75 & 1.43 & $0.27 * *$ & $0.29 * *$ & $0.30 * *$ & 0.70 & - & - & - & - \\
\hline 5. NC & 5.08 & 1.29 & $0.17 *$ & 0.08 & $0.62 * *$ & $0.34 * *$ & 0.82 & - & - & - \\
\hline 6. Pay satisfaction & 4.37 & 1.61 & 0.06 & 0.11 & -0.13 & $0.23 * *$ & -0.05 & 0.67 & - & - \\
\hline 7. Job security & 5.45 & 1.36 & $0.20 * *$ & $0.24 * *$ & $0.36 * *$ & $0.23 * *$ & $0.26 * *$ & -0.06 & - & - \\
\hline 8. Strike propensity & 1.98 & 1.21 & $-019 * *$ & $-0.21 * *$ & $-0.22 * *$ & $-0.26 * *$ & $-0.21 * *$ & -0.06 & $-0.17^{*}$ & 0.90 \\
\hline
\end{tabular}

$*, p<.05$

$n=187$. Alpha coefficients are in boldface on the diagonal.

$\mathrm{AC}$, affective commitment; $\mathrm{CC}$, continuance commitment; $\mathrm{NC}$, normative commitment.

a, age in years

,', organisational tenure in years

TABLE 4: Comparison of five-cluster and six-cluster solutions (study 1).

\begin{tabular}{llllll}
\hline Clusters & Profile & AC & CC & NC & $\boldsymbol{n}$ \\
\hline Five-cluster solution & Uncommitted & -1.171 & -0.067 & -0.520 & 31 \\
& Uncommitted & -1.437 & -1.304 & -1.705 & 19 \\
& AC-CC dominant & 0.007 & 0.735 & -0.643 & 28 \\
& AC-NC dominant & 0.264 & -0.997 & 0.236 & 43 \\
& Highly committed & 0.788 & 0.744 & 0.854 & 66 \\
Six-cluster solution & Uncommitted & -1.437 & -1.304 & -1.705 & 19 \\
& NC dominant & -0.663 & -0.306 & 0.335 & 31 \\
& CC midlevel & -1.085 & 0.033 & -1.094 & 20 \\
& AC-CC dominant & 0.045 & 0.878 & -0.702 & 23 \\
& AC-NC dominant & 0.545 & -1.194 & 0.132 & 29 \\
& Highly committed & 0.811 & 0.739 & 0.864 & 65 \\
\hline
\end{tabular}

$\mathrm{AC}$, affective commitment; $\mathrm{CC}$, continuance commitment; $\mathrm{NC}$, normative commitment.

RMSEA $=0.118$, TLI $=0.90$, CFI $=0.92$, GFI $=0.85)$ and onefactor $\left(\chi^{2} / d f=2.83\right.$, RMSEA $=0.145, \mathrm{TLI}=0.85, \mathrm{CFI}=0.88, \mathrm{GFI}=$ $0.81)$. Although GFI was slightly below the recommended threshold, this model was the best fit for the data, considering that the other indices (TLI, CFI) were high with significant item loadings, and no more items could be dropped. Also, the internal consistencies, assessed by Cronbach's alphas (Table 3) are equal to or greater than 0.70 , further supporting the adequacy of the measures used.

Descriptive statistics, in terms of means, standard deviations and correlations, are presented in Table 3. The correlations amongst the commitment components were in line with prior research (e.g. Meyer et al., 2002), with the strongest correlation occurring between $\mathrm{AC}$ and $\mathrm{NC}(r=0.62)$. Of particular note is the correlation involving job security, which was a single item measure; hence, the reliability estimate could not be determined. However, its positive correlation with age and tenure supports its face validity. Age and tenure are highly correlated, implying that those who are older might have stayed for longer; therefore, they have tenure and security in their jobs. The correlation with the commitment constructs, especially AC (0.36), is in line with prior postulations that job security correlates highly with affective commitment (e.g. Gaertner \& Nollen, 1989) and provides some support for its criterion validity.

\section{Commitment profiles}

The k-means cluster analytic procedure began with a request for an eight-cluster solution based on the postulation by

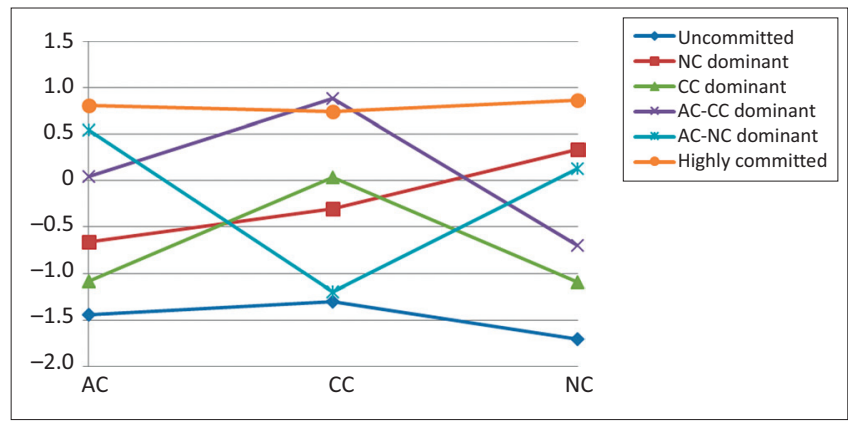

FIGURE 1: Profiles of organisational commitment (study 1).

Meyer and Herscovitch (2001). However, it became apparent that the eight-cluster solution was not tenable due to the cell sizes and an overlap of some cluster groups. Hence, fivecluster and six-cluster solutions were tested as the next logical step and are compared in Table 4. The six-cluster solution was deemed more acceptable and is presented in Figure 1. The comparative five-cluster solution had overlapping profiles - two uncommitted profiles - and was rejected. Since standardised scores were used in the cluster analysis, the mean score of zero was used as the cut-off point in labelling the profiles. As postulated by Meyer and Herscovitch (2001), two extreme profiles, characterised by above average $\mathrm{AC}, \mathrm{CC}$, and NC, and below average AC, CC, and NC were labelled highly committed and uncommitted respectively. Between these two, there were four other profiles: one profile reported below average $\mathrm{AC}$ and $\mathrm{CC}$, but above average $\mathrm{NC}$, and was labelled NC dominant. The next profile was characterised by below average $\mathrm{AC}$ and $\mathrm{NC}$, and slightly above average $\mathrm{CC}$, and was labelled CC dominant. Although the mean for CC is only slightly above the cut-off point, the means for $\mathrm{AC}$ and $\mathrm{NC}$ are well below zero (mean for z-scores). Another profile, characterised by above average $\mathrm{CC}$, slightly above average $\mathrm{AC}$ and below average NC, was labelled AC-CC dominant. The final profile was characterised by above average $A C$, slightly above average NC and below average $\mathrm{CC}$ and was labelled AC-NC dominant.

\section{Mean differences amongst commitment profiles}

The MANOVA outcome indicates that there were significant differences amongst the commitment groups for pay satisfaction, job security, strike propensity, age and tenure (Wilks's $\lambda=0.652 ; F=3.21, p<0.001$ ). This analysis was meant 
TABLE 5: Mean values of outcome variables across commitment profiles (study 1).

\begin{tabular}{|c|c|c|c|c|c|c|c|c|}
\hline Variable & $\begin{array}{l}\text { AC-NC } \\
\text { dominant } \\
\text { (1) }\end{array}$ & $\begin{array}{l}\text { NC dominant } \\
\text { (2) }\end{array}$ & $\begin{array}{l}\text { Uncommitted } \\
\text { (3) }\end{array}$ & $\begin{array}{l}\text { AC-CC } \\
\text { dominant } \\
\text { (4) }\end{array}$ & $\begin{array}{l}\text { Highly } \\
\text { committed } \\
(5)\end{array}$ & $\begin{array}{l}\text { CC dominant } \\
(6)\end{array}$ & Total & Post hoc \\
\hline $\begin{array}{l}\text { Pay satisfaction } \\
F(5,181)=4.04^{b} \\
\text { Partial } \eta^{2}=0.100\end{array}$ & $\begin{array}{l}3.31 \\
(1.44)\end{array}$ & $\begin{array}{l}4.22 \\
(1.09)\end{array}$ & $\begin{array}{l}4.57 \\
(1.93)\end{array}$ & $\begin{array}{l}4.82 \\
(1.48)\end{array}$ & $\begin{array}{l}4.48 \\
(1.73)\end{array}$ & $\begin{array}{l}5.05 \\
(1.37)\end{array}$ & $\begin{array}{l}4.37 \\
(1.61)\end{array}$ & $4^{a}, 5^{a}, 6^{b}>1$ \\
\hline $\begin{array}{l}\text { Job security } \\
F(5,181)=6.19^{b} \\
\text { Partial } \eta^{2}=0.146\end{array}$ & $\begin{array}{l}5.65 \\
(1.26)\end{array}$ & $\begin{array}{l}5.00 \\
(1.41)\end{array}$ & $\begin{array}{l}4.47 \\
(2.11)\end{array}$ & $\begin{array}{l}5.69 \\
(1.18)\end{array}$ & $\begin{array}{l}5.98 \\
(0.78)\end{array}$ & $\begin{array}{l}4.85 \\
(1.46)\end{array}$ & $\begin{array}{l}5.45 \\
(1.36)\end{array}$ & $5>2^{b}, 3^{a}$ \\
\hline $\begin{array}{l}\text { Strike propensity } \\
F(5,181)=4.80^{\mathrm{b}} \\
\text { Partial } \eta^{2}=0.117\end{array}$ & $\begin{array}{l}2.08 \\
(0.92)\end{array}$ & $\begin{array}{l}2.30 \\
(1.17)\end{array}$ & $\begin{array}{l}2.75 \\
(1.52)\end{array}$ & $\begin{array}{l}1.62 \\
(0.86)\end{array}$ & $\begin{array}{l}1.57 \\
(0.97)\end{array}$ & $\begin{array}{l}2.40 \\
(1.72)\end{array}$ & $\begin{array}{l}1.98 \\
(1.21)\end{array}$ & $3>5^{a}$ \\
\hline $\begin{array}{l}\text { Age } \\
F(5,181)=2.38^{a} \\
\text { Partial } \eta^{2}=0.092\end{array}$ & $\begin{array}{l}38.13 \\
(11.00)\end{array}$ & $\begin{array}{l}36.58 \\
(12.13)\end{array}$ & $\begin{array}{l}31.63 \\
(8.83)\end{array}$ & $\begin{array}{l}40.90 \\
(12.31)\end{array}$ & $\begin{array}{l}40.76 \\
(12.89)\end{array}$ & $\begin{array}{l}35.25 \\
(13.02)\end{array}$ & $\begin{array}{l}38.19 \\
(12.16)\end{array}$ & $4,5>3^{a}$ \\
\hline $\begin{array}{l}\text { Tenure } \\
F(5,181)=2.48^{a} \\
\text { Partial } \eta^{2}=0.064\end{array}$ & $\begin{array}{l}8.68 \\
(5.93)\end{array}$ & $\begin{array}{l}7.83 \\
(6.25)\end{array}$ & $\begin{array}{l}6.15 \\
(3.80)\end{array}$ & $\begin{array}{l}11.91 \\
(6.20)\end{array}$ & $\begin{array}{l}9.63 \\
(5.58)\end{array}$ & $\begin{array}{l}8.75 \\
(6.34)\end{array}$ & $\begin{array}{l}8.90 \\
(5.88)\end{array}$ & $4>3^{a}$ \\
\hline
\end{tabular}

a, $p<0.05$

b, $p<0.01$. Wilks's $\lambda=0.652(F=3.21 ; p<0.001)$; Observed power (multivariate test $)=0.999$

to test the discriminant validity of the profiles that emerged, with respect to research questions 2 and 3. The follow-up ANOVA with Scheffe post hoc multiple comparisons are presented in Table 5. This finding indicates univariate differences in all the outcome variables and the demographic factors, with comparable effect sizes ranging from 0.62 to 1.46. The results show that the highly committed and the CC combined profiles (AC-CC dominant and CC dominant) experienced higher pay satisfaction than the AC-NC group. The highly committed group also experienced greater job security than the NC dominant and the uncommitted groups. With respect to respondents' propensity to strike, the mean score for the uncommitted group seems higher than all the other groups, but is only statistically significant compared to the highly committed group. Together, these suggest that the highly committed and the CC-combined profiles are more associated with the positive outcomes than the NC-combined profiles.

For the demographic variables, only a few differences were observed, showing that the highly committed and the AC-CC groups appear older than the uncommitted group and the AC-CC dominant group reported a higher level of organisational tenure than the uncommitted group.

\section{Study 2 \\ Method}

\section{Participants and procedure}

Data for this study was collected as part of a bigger project to examine the influence of perceived inflation on employee attitude and performance in unionised employment contexts. Although the data for study 2 has not been published yet, it may be considered secondary since it was not originally collected for profile analysis. The data was collected using the 'paper and pencil' with on-site administration of questions (drop-off) through the human resources department and union representatives in three organisations (in mining, manufacturing and health care industries). The number of surveyed employees from the three sites was 1005 and 218 usable responses were returned $(21.69 \%$ response rate). The demographic distribution of respondents indicates that women make up only $37.6 \%$ of this sample, which is representative of the industries studied, especially in the mining and cement manufacturing sectors. The mean age of respondents was 37.98 years $(\mathrm{SD}=11.24)$ and the mean organisational tenure was 11.24 years $(\mathrm{SD}=8.42)$. Over half $(54 \%)$ of the sample reported having an associate degree or less.

\section{Measures}

Organisational commitment was measured with a refinement of the Meyer and Allen scale by Lee, Allen, Meyer \& Rhea (2001). The scale includes five items each for affective $(\alpha=0.85)$ and normative $(\alpha=0.68)$ commitment and a modified five-item scale for continuance commitment $(\alpha=0.72)$. Researchers have argued that the continuance commitment component is equivalent to personal cost of leaving (Ko, Price \& Mueller, 1997; Meyer et al., 2002; Powell \& Meyer, 2004) and that the lack of alternative items may serve as its antecedent. Hence, two items representing perceived lack of alternatives on the CC scale were dropped and replaced by two items from Wasti (2002): 'The longer I stay with this organisation, the harder it is for me to leave' and 'I would not want to start from scratch at another organisation'. Psychological collectivism was measured with six items ( $\alpha=0.77)$ adapted from Clugston et al. (2000). Job security was measured with two items from Sun, Aryee and Law's (2007) high-performance human resource practice measure $(\alpha=0.73)$ : 'Employees in this job can be expected to stay with this organisation for as long as they wish' and 'Job security is almost guaranteed to employees in this job'.

\section{Data analysis}

As in study 1, commitment profiles were extracted using k-means clustering with z-scores. MANOVA was used to test for differences amongst profiles on two contextual variables (job security and psychological collectivism) and demographic variables (age and organisational tenure).

\section{Results}

Using the threshold enumerated in study 1, the CFA proves the adequacy of the three-component model with the following fit statistics: $\chi^{2} / d f=1.94$, RMSEA $=0.066$, TLI $=0.95$, 
TABLE 6: Means, standard deviations, and correlations amongst the study variables (study 2).

\begin{tabular}{|c|c|c|c|c|c|c|c|c|c|}
\hline Variable & Mean & SD & 1 & 2 & 3 & 4 & 5 & 6 & 7 \\
\hline 1. $\mathrm{Age}^{\mathrm{a}}$ & 37.98 & 11.24 & - & - & - & - & - & - & - \\
\hline 2. Tenure $^{\mathrm{b}}$ & 11.24 & 8.42 & $0.74 * *$ & - & - & - & - & - & - \\
\hline 3. $A C$ & 5.55 & 1.29 & 0.03 & 0.06 & 0.85 & - & - & - & - \\
\hline 4. CC & 4.57 & 1.49 & 0.09 & $0.19 * *$ & $0.24 * *$ & 0.72 & - & - & - \\
\hline 5. NC & 4.68 & 1.30 & $-0.14 *$ & -0.06 & 0.13 & $0.40 * *$ & 0.68 & - & - \\
\hline 6. Job security & 5.73 & 1.21 & $0.19 * *$ & $0.19 * *$ & $0.14 *$ & $0.20 * *$ & 0.10 & 0.73 & - \\
\hline 7. Collectivism & 3.68 & 0.84 & 0.00 & -0.08 & $0.22 * *$ & $0.18 * *$ & 0.09 & 0.12 & 0.77 \\
\hline
\end{tabular}

$*, p<.05$

$* *, p<.01$

$n=218$. Alpha coefficients are in boldface on the diagonal

$\mathrm{AC}$, affective commitment; CC, continuance commitment; $\mathrm{NC}$, normative commitment.

a, age in years

b, organisational tenure in years

TABLE 7: Comparison of five-cluster and six-cluster solutions (study 2).

\begin{tabular}{llllll}
\hline Clusters & Profile & AC & CC & NC & $n$ \\
\hline Five-cluster solution & Uncommitted & -1.324 & -1.344 & -1.259 & 15 \\
& NC dominant & -1.912 & -0.340 & 0.465 & 16 \\
& CC dominant & -0.656 & 0.382 & -0.773 & 32 \\
& AC dominant & 0.339 & -0.890 & -00.487 & 61 \\
& Highly committed & 0.540 & 0.720 & 0.701 & 94 \\
Six-cluster solution & Uncommitted & -1.789 & -1.472 & -0.874 & 11 \\
& NC dominant & -01.912 & -0.340 & -0.465 & 16 \\
& CC dominant & -0.697 & 0.438 & -0.737 & 29 \\
& AC dominant & 0.456 & -1.073 & -1.847 & 18 \\
& AC-NC midlevel & 0.291 & -0.643 & 0.037 & 65 \\
& Highly committed & 0.548 & 0.887 & 0.688 & 79 \\
\hline
\end{tabular}

$\mathrm{AC}$, affective commitment; $\mathrm{CC}$, continuance commitment; $\mathrm{NC}$, normative commitment.

$\mathrm{CFI}=0.97$, GFI $=0.95$. Thus, the three-factor solution was a better fit to the data than the competing models examined: two-factor $\left(\chi^{2} / d f=7.65, \mathrm{RMSEA}=0.175, \mathrm{TLI}=0.72, \mathrm{CFI}=0.80\right.$, $\mathrm{GFI}=0.83)$ and one-factor $\left(\chi^{2} / d f=13.85\right.$, RMSEA $=0.243$, $\mathrm{TLI}=0.52, \mathrm{CFI}=0.64, \mathrm{GFI}=0.72$ ). Items loaded significantly onto their respective constructs (three items each for AC, CC and $\mathrm{NC}$, equivalent to the condensed scales), with significant loadings ranging from 0.60 to 0.84 . The internal consistencies assessed by the Cronbach's alphas (Table 6) are greater than 0.70 , except NC (0.68), although this is acceptable (Hair et al., 2006).

Descriptive statistics, in terms of means, standard deviations and correlations are presented in Table 6 . The pattern of correlation involving the refined CC scale and the other components of commitment were in line with prior research and similar to those of study 1. CC correlated positively with AC (0.24) and NC (0.40). Also, the CC scale correlated positively with job security $(0.20)$ as in study 1 . Moreover, as reported in study 1 , job security correlated positively with age and tenure, which are both highly correlated. Thus, those who feel secure on their job will stay longer and achieve high tenure (aged).

\section{Commitment profiles}

In view of the small sample size as revealed in study 1 , only five-cluster and six-cluster solutions were compared; the result is presented in Table 7 . Both five-cluster and six-cluster solutions looked similar except for the AC-NC profile in the six-cluster solution. Hence, the six-cluster solution, represented in Figure 2, was deemed acceptable, because it is the closest to

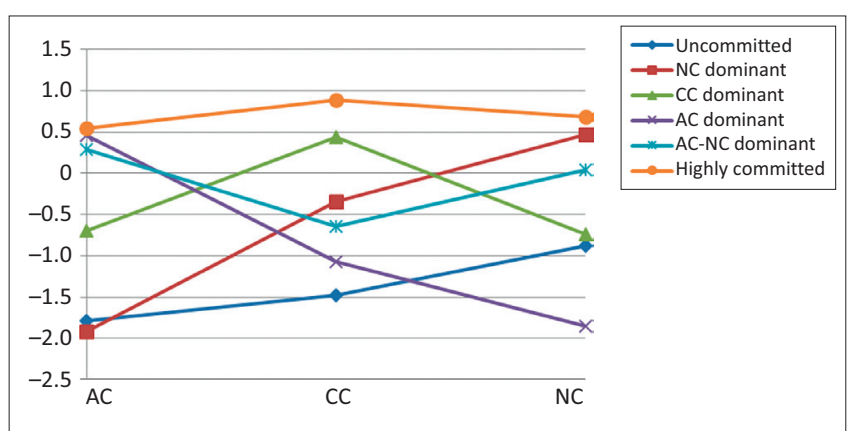

FIGURE 2: Profiles of organisational commitment (study 2).

the hypothesised eight-cluster solution, with enough cell sizes to allow for mean comparisons. Also, the cell membership is better distributed in the six-cluster than the five-cluster solution that has one cell containing $43.11 \%$ of the sample population (compared to $36.23 \%$ ). As in study 1, the z-score average (zero) was used as the cut-off point in characterising the profiles. The two extreme profiles, characterised by above and below average AC, CC and NC, were labelled highly committed and uncommitted respectively. For the other four, one profile was characterised by below average AC and CC, but above average $\mathrm{NC}$, and was labelled $\mathrm{NC}$ dominant. The next profile reports below average $\mathrm{AC}$ and NC, but above average $\mathrm{CC}$, and was labelled CC dominant. Another profile was characterised by below average $\mathrm{CC}$ and $\mathrm{NC}$, but above average $\mathrm{AC}$, and was labelled $A C$ dominant. The final profile, which was characterised by below average $\mathrm{CC}$, but slightly above average AC and NC was labelled $A C-N C$ dominant.

\section{Mean differences amongst commitment profiles}

The MANOVA outcome indicates that there were significant differences amongst the commitment groups for only job security and psychological collectivism (Wilks's $\lambda=0.779$; $F=2.654, p<0.001$ ), with effect sizes of 0.105 and 0.094 respectively. The follow-up ANOVA with Scheffe post hoc comparisons (Table 8) shows that most of the profile groups (except NC dominant and AC-NC dominant) experienced higher levels of job security than the uncommitted group. For psychological collectivism, three profile groups (AC dominant, AC-NC dominant and highly committed) reported higher levels of psychological collectivism than the uncommitted group. However, the demographic variables (age and tenure) were not significant in discriminating amongst the profile groups in this study. 
TABLE 8: Mean values of outcome variables across commitment profiles (study 2).

\begin{tabular}{|c|c|c|c|c|c|c|c|c|}
\hline Variable & $\begin{array}{l}\text { NC dominant } \\
\text { (1) }\end{array}$ & $\begin{array}{l}\text { Uncommitted } \\
\text { (2) }\end{array}$ & $\begin{array}{l}\text { CC dominant } \\
\text { (3) }\end{array}$ & $\begin{array}{l}\text { AC dominant } \\
\text { (4) }\end{array}$ & $\begin{array}{l}\text { AC-NC dominant } \\
\text { (5) }\end{array}$ & $\begin{array}{l}\text { Highly committed } \\
\text { (6) }\end{array}$ & Total & Post hoc \\
\hline $\begin{array}{l}\text { Job security } \\
F(5,207)=5.00^{b} \\
\text { Partial } \eta^{2}=0.108\end{array}$ & $\begin{array}{l}5.65 \\
(1.31)\end{array}$ & $\begin{array}{l}4.18 \\
(2.19)\end{array}$ & $\begin{array}{l}5.83 \\
(1.15)\end{array}$ & $\begin{array}{l}5.88 \\
(0.74)\end{array}$ & $\begin{array}{l}5.60 \\
(1.35)\end{array}$ & $\begin{array}{l}6.00 \\
(0.79)\end{array}$ & $\begin{array}{l}5.73 \\
(1.21)\end{array}$ & $2<3^{b}, 4^{a}, 6^{b}$ \\
\hline $\begin{array}{l}\mathrm{COL} \\
F(5,207)=4.29^{\mathrm{b}} \\
\text { Partial } \eta^{2}=0.094\end{array}$ & $\begin{array}{l}3.64 \\
(0.54)\end{array}$ & $\begin{array}{l}2.69 \\
(0.89)\end{array}$ & $\begin{array}{l}3.50 \\
(0.80)\end{array}$ & $\begin{array}{l}3.94 \\
(0.67)\end{array}$ & $\begin{array}{l}3.70 \\
(0.72)\end{array}$ & $\begin{array}{l}3.81 \\
(0.93)\end{array}$ & $\begin{array}{l}3.68 \\
(0.84)\end{array}$ & $2<4^{a}, 5^{a}, 6^{b}$ \\
\hline $\begin{array}{l}\text { Age } \\
F(5,207)=1.57 \\
\text { Partial } \eta^{2}=0.037\end{array}$ & $\begin{array}{l}36.28 \\
(12.32)\end{array}$ & $\begin{array}{l}31.45 \\
(7.01)\end{array}$ & $\begin{array}{l}40.53 \\
(12.47)\end{array}$ & $\begin{array}{l}37.50 \\
(9.47)\end{array}$ & $\begin{array}{l}37.73 \\
(9.82)\end{array}$ & $\begin{array}{l}36.82 \\
(10.59)\end{array}$ & $\begin{array}{l}37.29 \\
(10.55)\end{array}$ & ns \\
\hline $\begin{array}{l}\text { Tenure } \\
F(5,207)=1.28 \\
\text { Partial } \eta^{2}=0.030\end{array}$ & $\begin{array}{l}9.50 \\
(6.92)\end{array}$ & $\begin{array}{l}6.77 \\
(4.12)\end{array}$ & $\begin{array}{l}13.35 \\
(9.55)\end{array}$ & $\begin{array}{l}10.91 \\
(6.88)\end{array}$ & $\begin{array}{l}10.73 \\
(8.14)\end{array}$ & $\begin{array}{l}11.96 \\
(9.09)\end{array}$ & $\begin{array}{l}11.24 \\
(8.42)\end{array}$ & ns \\
\hline
\end{tabular}

a, $p<0.05$

', $p<0.01$. Wilks's $\lambda=0.779(F=2.654 ; p<0.001)$; Observed power (multivariate test) $=0.994$

\section{General discussion}

The objective of this study was to test the applicability of the profile typology postulated by Meyer and Herscovitch (2001) in Ghana, an African context. Based on data from two studies, the profiles of commitment may generalise to this context, although without support for the hypothesised eight-cluster solution. The emergent profiles across both studies include the highly committed and the uncommitted groups, the AC-NC dominant group (moral imperatives), the $\mathrm{CC}$ and $\mathrm{NC}$ dominant groups (trapped and obligated respectively), the $\mathrm{AC}$ dominant group (attached) and the AC-CC dominant group (invested). The AC-NC group includes employees who have both the desire and moral obligation to stay; they are referred to as moral imperatives, whilst employees in the AC dominant group with only the desire to stay are known as the attached (Sinclair et al., 2005). Similarly, employees in the AC-CC dominant group have both desire and cost-based reasons (e.g. financial needs) to stay and, therefore, they are described as the invested, whilst the CC dominant group employees with only cost-based attachment are referred to as trapped and the NC dominant group employees are known as the obligated. Five profiles out of the six-cluster solutions that emerged in both studies were similar. Thus, the observed difference between the two studies was the emergence of the AC-CC dominant profile in study 1 and the AC dominant profile in study 2. This outcome could be attributed to a number of possible reasons including the sample size, the organisation or the industry of study. Another plausible reason is the increased agitation for better working conditions by health workers (study 1) in the country; hence, CC may be important to their psychology of commitment.

Obviously, the small sample sizes in the two studies compared to previous studies on profiles may have contributed to our inability to extract the theoretically postulated eight-cluster solution. However, reproducing less than an eight-cluster solution is not unusual since very few researchers have replicated the eight-profile typology (except Gellatly et al., 2006). A number of studies have reported fewer clusters than the hypothetical eight-cluster solution, including research in non-Western settings (e.g. Tsoumbris \& Xenikou, 2010; Wasti, 2005), see Table 2. However, theoretically, all the types of profiles postulated by Meyer and Herscovitch (2001) emerged across the two studies (when counting profiles in both studies), except for the NC-CC dominant profile which did not emerge in any of the studies. Amongst the well-documented profiles in the literature are the fully committed, AC-NC dominant, CC dominant and the uncommitted groups (Meyer et al., 2012), which were all replicated in both studies, supporting the credibility of the emerged clusters in this context. In addition, the NC dominant profile emerged in the two studies, although this profile is hardly reported in the literature (Kam et al., 2013). This finding suggests the salience of NC in this collectivist setting, as asserted in the literature (e.g. Wasti, 2002). Also, commitment influenced by economic factors is salient in this setting since the country is classified as developing (The World Bank, 2012). These outcomes together suggest that the typology of commitment profiles is generalisable to Ghana, an African context.

The analysis of the mean differences amongst the profiles revealed that the uncommitted group reported lower mean scores on the positive outcome variables (pay satisfaction, job security), but a higher score on the negative organisational outcome (propensity to strike). The only outcome concerning mean difference that was replicated in both studies was job security since it was the only outcome variable measured in both studies, though with different items. As was expected, the highly committed group in both studies felt more secure in their jobs than the uncommitted, in spite of the different items used. The highly committed group, the AC-CC dominant group and the CC dominant group reported higher levels of pay satisfaction in study 1 . Health care workers may be amongst some of the well-paid workers in Ghana (GhanaNation, 2012), especially after the implementation of a universal pay system. Continuance commitment is cost based (financial need); hence, those who may have invested their time, effort and resources in the organisation (the invested) or those who may feel trapped may be in for the economic accruals including pay. This is especially true for a country with low percapita income (high economic need country) such as Ghana (The World Bank, 2012). For these groups, pay may be an important factor for their overall involvement in the organisation. Conversely, for the AC-NC group (moral imperatives) who may be immersed in their work, pay may not be at the top of their concerns in employment relations. 
Since the highly committed and AC-CC dominant groups reported higher mean level for positive work outcomes, CC may not have attenuated the effect of AC as asserted by Meyer and Herscovitch (2001). Kam et al. (2013) assert that casting commitment as a profile for each employee, including CC, offers a more holistic view of the concept that moves away from an AC-centric model. The uncommitted group expectedly reported higher mean levels of strike propensity. Thus, those who feel unattached are more likely to experience negative attitudes and behaviours on the job, including stoppage.

With respect to psychological collectivism, the outcome is contrary to what we expected, in terms of the relationship between commitment and culture. For example, Clugston et al. (2000) found that collectivism was highly related to normative commitment, but in this study, the purely NC group did not report higher collectivism than the other groups. Instead, the highly committed, and the AC and AC-NC dominant groups reported higher level of collectivism. It has been noted that the emotional desire to stay with the organisation may be accompanied by obligated tendencies amongst collectivists due to the generalised cultural expectations (Wasti, 2002). The non-association of NC, though surprising, could be due to the different approaches to the study of commitment. Assertions about NC and culture are based on variablecentred approach to the study of commitment (Meyer et al., 2012), whilst this study is person-centred. Although it has been argued that the profile approach would augment the variable-centred findings, this is not the case with the NC profile in this study. This outcome could also be due to the NC scale in study 2; only three items loaded significantly with an alpha value below the recommended threshold. The NC dominant profile emerged in both studies, but the relation with collectivism was only examined in study 2 because collectivism was not measured in study 1 . It should be noted that the samples used in this article were two different studies conducted on two different occasions with different goals. The NC dominant profile is not amongst the popular profiles reported in previous studies; hence, further tests would be required before a firm conclusion may be drawn.

The outcome with respect to the demographic factors (significant only in study 1) is in line with past research findings, which have shown that age and tenure are associated with high commitment (Mathieu \& Zajac, 1990; Meyer et al., 2002). The highly committed and AC-CC dominant groups may be older and have higher tenure than the uncommitted group. Sinclair et al. (2005) assert that those who are not committed may exit the organisation by self-selection. Since age and tenure are highly correlated, the invested group who have both the desire and the need to stay may have stayed longer with the organisation and, hence, accrued tenure. Thus, when one is invested in the organisation, one is likely to stay longer. These should be amongst the most experienced employees and an important source of human capital for the organisation. This outcome, however, was not replicated in study 2 because the AC-CC group did not emerge in this sample.
Clearly, this study is not without limitations, particularly the small sample sizes used in the profile analysis. For example, two of the clusters in study 2 had cluster sizes that were below $10 \%$ of the sample size, but this includes the uncommitted group. Having a small cell size for the uncommitted group should not be entirely surprising and may even be beneficial to the organisation since these individuals may self-select out of the organisation (Sinclair et al., 2005). However, it could potentially affect the power of the analysis, although significant mean differences were found that are theoretically sound, even with a more conservative post hoc test (Scheffe). In addition, sampling only one country is not representative enough to generalise the specific outcome beyond the West African region. However, the finding in this study is significant and important in terms of theory testing and application. African countries may be different in a number of respects, including culture, but they may share similar job attitudes like commitment, job satisfaction, job security and so on. For instance, research has shown that the three-component model of commitment is generalisable to other African contexts (e.g. Beukes \& Botha, 2013; Bosman et al., 2005; Simons \& Buitendach, 2013). Hence, researchers may further test the theoretical postulations of commitment profiles by designing studies that will sample multiple countries in Africa, with larger sample sizes to enable the test of the postulated eight-cluster solution.

Further, the data sets employed in this study are crosssectional data: data collected over a single period without manipulation of the respondents or the environment. Hence, cause-and-effect relationships cannot be inferred from the findings in this study, as it does not consider what happens before or after the responses were elicited. Moreover, the data may be viewed as secondary since it was not originally intended for configural analysis. Therefore, the full range of potential variables, including performance, turnover and absenteeism, could not be examined in this study. This study only focused on contextual and demographic variables. For instance, we only used two items as proxy for pay level satisfaction: a single dimension of the multi-factor pay satisfaction measure. However, this does not negate the findings, but rather it indicates the need for further tests to validate the outcomes reported in this study. Thus, future research may investigate commitment profiles in this region, focusing on outcome variables such as in-role performance, citizenship, absenteeism and turnover intentions, as suggested by Meyer and Herscovitch (2001).

Again, different outcome variables and measures were used in the two studies, except for the demographic factors. For the commitment measures, some of the items, especially, the CC items were different, as a refined CC scale was used in study 2. Future field studies on commitment profiles should be designed to examine the same variables and to elicit responses using the same measures in multi-sample studies over a number of periods. The different outcomes from the two cross-sectional data sets suggest the need to examine the 
temporal stability of the commitment profiles in Ghana. Kam et al. (2013) reported in their study in Canada that profile membership may be stable over time, but it remains to be determined if profile membership will stabilise over time in Ghana or other African contexts.

\section{Conclusion}

The limitations notwithstanding, the findings of this study provide preliminary evidence of the applicability of commitment profiles to Ghana. Hence, it is the first step towards testing the profile approach and its generalisability to the African context. Although the profiles that emerged in the two samples are similar, the outcome also suggests different profiles may emerge in different contexts and that the profiles that emerge may depend on the sample, the organisation or the industry of study. The level of one commitment component may influence the effect of other components and profiles dominated by CC and NC may also be salient and may augment the influence of $\mathrm{AC}$ on positive work outcomes. Thus, different patterns of commitment may associate differently with positive and negative work outcomes, with implications for organisations. Researchers interested in examining commitment and its outcomes in Ghana or other African contexts may employ the configural approach to the study of commitment.

\section{Acknowledgements}

\section{Competing interests}

The authors declare that they have no financial or personal relationship(s) that may have inappropriately influenced them in writing this article.

\section{Authors' contributions}

E.O.A (Henderson State University) was responsible for the study concept and design, data analysis and writing up the article. E.V.A. (North Carolina Central University) made conceptual contributions and aided in writing the manuscript and editing the final manuscript.

\section{References}

Akoto, E.O., \& Stammerjohan, C.A. (in press). Moderating effect of perceived inflation on dual commitment to organisation and professional association: A case of health professionals in Ghana. African Journal of Economic and Management Studies.

Allen, N.J., \& Meyer, J.P. (1990). The measurement and antecedents of affective, continuance, and normative commitment to the organisation. Journal of Occupational Psychology, 63, 1-18. http://dx.doi.org/10.1111/j.2044-8325.1990. tb00506.x

Beukes, I., \& Botha, E. (2013). Organisational commitment, work engagement and meaning of work of nursing staff in hospitals. SA Journal of Industrial Psychology/ SA Tydskrif vir Bedryfsielkunde, 39, Art. \#1144, 10 pages. http://dx.doi. org/10.4102/sajip.v39i2.1144

Bosman, B., Buitendach, J.H., \& Laba, K. (2005). Job insecurity, burnout and organisational commitment among employees of a financial institution in Gauteng. SA Journal of Industrial Psychology/SA Tydskrif vir Bedryfsielkunde, 31 32-40. http://dx.doi.org/10.4102/sajip.v31i4.210

Clugston, M., Howell, J.P., \& Dorfman, P.W. (2000). Does cultural socialization predict multiple bases and foci of commitment? Journal of Management, 26, 1-30. http://dx.doi.org/10.1016/S0149-2063(99)00034-3

Cohen, A. (1992). Attitudinal militancy and propensity to strike among unionized engineers and $\mathrm{x}$-ray technicians. Human Relations, 45, 1333-1366. http://dx.doi. org/10.1177/001872679204501205
Cohen, A. 2005. Dual commitment to the organisation and the union: A multi-dimensional approach. Relations Industrielles, 60, 432-566. http://dx.doi. org/10.7202/012154ar

Gaertner, K.N., \& Nollen, S.D. (1989). Career experiences, perceptions of employment practices, and psychological commitment to the organisation. Human Relations, 42, 975-991. http://dx.doi.org/10.1177/001872678904201102

Gellatly, I., Meyer, J., \& Luchak, A. (2006). Combined effects of the three commitment components on focal and discretionary behaviours: A test of Meyer and Herscovitch's propositions. Journal of Vocational Behaviour, 69, 331-345. http:// dx.doi.org/10.1016/j.jvb.2005.12.005

Ghana News Agency (GNA). (2011, 12 October). Doctors strike impacts on police and 37 military hospitals. Retrieved October 15, 2011, from http://www. ghananewsagency.org/details/Health/Doctors-strike-impacts-on-Police-and-37Military-Hospitals/?ci=1\&ai=34589- .UJGKKGfO-So

GNA. (2006, 29 July). Civil servants threaten nationwide strike by Tuesday August 15th. Retrieved July 15, 2008, from http://www.ghananewsagency.org/ details/Social/Civil-servants-threaten-nationwide-strike-by-Tuesday-August$15 /$ ? ci=4andai $=200$.

GhanaNation. (2012). 50 highest paying occupations. Retrieved May 16, 2014, from http://news1.ghananation.com/careers/257376-50-highest-paying-occupations. html

Hair, J.F.J., Anderson, R.E., Tatham, R.L., \& Black, W.C. (2006). Multivariate data analysis. Englewood Cliffs, NJ: Prentice Hall.

Heneman, H.G. III, \& Schwab, D.P. (1985). Pay satisfaction: Its multidimensional nature and measurement. International Journal of Psychology, 20, 129-141. http:// dx.doi.org/10.1080/00207598508246743

Hofstede, G. (2001). Cultural consequences: Comparing values, behaviors, institutions, and organisations across nations. Thousand Oaks, CA: Sage.

House, R.I., Hanges, P.I., Javidan, M., Dorfman, P.I., \& Gupta, V. (2004). Culture, leadership and organisations: The globe study of 62 societies. Thousand Oaks, CA: Sage Publishers.

Kam, C., Morin, A.J.S., Meyer, J.P., \& Topolnytsky, L. (2013). Are commitment profiles stable and predictable? A latent transition analysis. Journal of Management Advance online publication. Retrieved September 12, 2014, from http://jom. sagepub.com/content/early/2013/09/11/0149206313503010

Klein, H.J., Brinsfield, C.T., \& Molloy, J.C. (2006). Understanding workplace commitments independent of antecedents, foci, rationales, and consequences. Paper presented at the Academy of Management Annual Meeting, Atlanta, GA 11-16 August.

Klein, H.J., Molloy, J.C., \& Cooper, J.T. (2009). Conceptual foundations: Construct definitions and theoretical representations of workplace commitments. In H.J. Klein, T.E. Becker, \& J.P. Meyer (Eds.), Commitment in organisations: Accumulated wisdom and new directions (pp. 3-36). New York, NY: Routledge.

Ko, J.-W., Price, J.L., \& Mueller, C.W. (1997). Assessment of Meyer and Allen's three-component model of organizational commitment in South Korea. Journal of Applied Psychology, 82, 961-973. http://dx.doi.org/10.1037/00219010.82.6.961

Lee, K., Allen, N.J., Meyer, J.P., \& Rhea, K.-Y. (2001). Cross-cultural generalisability of the three-component model of organisational commitment: An application to South Korea. Applied Psychology: An International Review, 50, 596-614. http:// dx.doi.org/10.1111/1464-0597.00075

Mathieu, J.E., \& Zajac, D.M. (1990). A review and meta-analysis of the antecedents, correlates, and consequences of organisational commitment. Psychological Bulletin, 108, 171-194. http://dx.doi.org/10.1037/0033-2909.108.2.171

Meyer, J.P., \& Allen, N.J. (1991). A three-component conceptualization of organisational commitment. Human Resource Management Review, 1, 61-89. http://dx.doi.org/10.1016/1053-4822(91)90011-Z

Meyer, J.P., \& Herscovitch, L. (2001). Commitment in the workplace: Toward a general model. Human Resource Management Review, 11, 299-326. http://dx.doi. org/10.1016/S1053-4822(00)00053-X

Meyer, J.P., Stanley, D.J., Herscovitch, L., \& Topolnytsky, L. (2002). Affective, continuance, and normative commitment to the organisation: A meta-analysis of the antecedents, correlates, and consequences. Journal of Vocational Behaviour 60, 20-52. http://dx.doi.org/10.1006/jvbe.2001.1842

Meyer, J.P., Stanley, D.J., Jackson, T.A., McInnis, K.J., Maltin, E.R., \& Sheppard, L. (2012). Affective, normative, and continuance commitment levels across cultures: A meta-analysis. Journal of Vocational Behavior, 80, 225-245. http://dx.doi. org/10.1016/j.jvb.2011.09.005

Meyer, J.P., Stanley, L.J., \& Vandenberg, R.J. (2013). A person-centered approach to the study of commitment. Human Resource Management Review, 23, 190-202. http://dx.doi.org/10.1016/j.hrmr.2012.07.007

Ministry of Health (MoH). (2007). Human resource policies and strategies for the health sector 2007-2011. Ministry of Health Report (September). Ghana: MoH.

Powell, D.M., \& Meyer, J.P. (2004). Side-bet theory and the three-component model of organisational commitment. Journal of Vocational Behaviour, 65, 157-177. http:// dx.doi.org/10.1016/S0001-8791(03)00050-2

Simons, J.C., \& Buitendach, J.H. (2013). Psychological capital, work engagement and organisational commitment amongst call centre employees in South Africa. SA Journal of Industrial Psychology/SA Tydskrif vir Bedryfsielkunde, 39, Art. \#1071, 12 pages. http://dx.doi.org/10.4102/sajip.v39i2.1071.

Sinclair, R., Tucker, J., Cullen, J., \& Wright, C. (2005). Performance differences amon four commitment profiles. Journal of Applied Psychology, 90, 1280-1287. http:// dx.doi.org/10.1037/0021-9010.90.6.1280 
Somers, M.J. (2009). The combined influence of affective, continuance, and normative commitment on employee withdrawal. Journal of Vocational Behaviour, 74, 75-81. http://dx.doi.org/10.1016/j.jvb.2008.10.006

Spector, P.E. (1997). Job satisfaction: Application, assessment, causes, and consequences. Thousand Oaks, CA: Sage.

Sun, L.-Y., Aryee, S., \& Law, K.S. (2007). High-performance human resource practices, citizenship behaviour, and organisational performance: A relational perspective. Academy of Management Journal, 50, 558-577. http://dx.doi.org/10.5465/ AMJ.2007.25525821

The World Bank. (2012). Ghana: World development indicators. Retrieved May 14 2014, from http://data.worldbank.org/country/ghana

Tsoumbris, P., \& Xenikou, A. (2010). Commitment profiles: The configural effect of the forms and foci of commitment on work outcomes. Journal of Vocational Behaviour, 77, 401-411. http://dx.doi.org/10.1016/j.jvb.2010.07.006
Vandenberghe, C., \& Tremblay, M. (2008). The role of pay satisfaction and organisational commitment in turnover intentions: A two-sample study. Journal
of Business Psychology, 22, 275-286. http://dx.doi.org/10.1007/s10869-008of Busines

Wasti, S.A. (2002). Affective and continuance commitment to the organisation: Test of an integrated model in the Turkish context. International Journal Test of an integrated model in the Turkish context. International Journal
of Intercultural Relations, 26, 525-550. http://dx.doi.org/10.1016/S01471767(02)00032-9

Wasti, S.A. (2005). Commitment profiles: Combinations of organisational commitment forms and job outcomes. Journal of Vocational Behaviour, 67, 290-308. http:// dx.doi.org/10.1016/j.jvb.2004.07.002

Williams, M.L., McDaniel, M.A., \& Nguyen, N.T (2006). A meta-analysis of the antecedents and consequences of pay level satisfaction. Journal of Applied Psychology, 9, 392-413. http://dx.doi.org/10.1037/0021-9010.91.2.392 